\title{
FDI, Corruption and Development of Public Service Sectors in ASEAN Countries
}

\author{
Nghi Huu PHAN ${ }^{1}$, Loan Quynh Thi NGUYEN ${ }^{2}$
}

Received: June 24, 2020 Revised: July 12, 2020 Accepted: August 10, 2020

\begin{abstract}
This study aims to empirically examine the effect of foreign direct investment (FDI) and corruption on the development of public-service sectors in 10 ASEAN countries. It then investigates whether this relationship is different between two FDI compositions including greenfield FDI and FDI in the form of cross-border merger and acquisitions (M\&As). Using a panel database of 10 ASEAN countries during the period 1996-2015 from various sources including the World Development Indicators of the World Bank and UNCTAD, we first find that FDI strongly and positively contributes to the development of the public-service sectors in the recipient nations, except for the electricity sector. However, we show that this relationship is dependent on the type of FDI modes of entry. Specifically, while greenfield investment exerts a beneficial influence on the development of telecommunication and transportation sectors, cross-border M\&A has no effect on these sectors, perhaps because of the distinct differences among three public service sectors. Finally, we found that in a highly corrupt environment, aggregate FDI might have no influence on all three public-service sectors, possibly because the two contradictory influences of the interaction terms between corruption and two FDI sub-types seem to cancel each other out.
\end{abstract}

Keywords: FDI, Corruption, Telecommunication, Transportation, Electricity

JEL Classification Code: A11, B41, E22, H54, O18

\section{Introduction}

In a general sense, FDI may contribute to the development of the host country by increasing the stock of knowledge via the spillover effects from FDI investors to local firms and by fostering technological growth via the incorporation of new inputs and foreign technologies in the production of the host country. Unfortunately, the empirical literature examining the impacts of FDI on receiving countries reveals rather mixed and inconclusive outcomes. While a strand of evidence has documented a positive developmental effect of FDI

${ }^{1}$ First Author. Lecturer, School of Banking and Finance, National Economics University, Vietnam. Email: nghiph.neu@gmail.com ${ }^{2}$ Corresponding Author. Lecturer, School of Banking and Finance, National Economics University, Vietnam [Postal Address: 207 Giai Phong Road, Dong Tam Ward, Hai Ba Trung District, Hanoi, 116000, Vietnam] Email: loanntq@neu.edu.vn

(c) Copyright: The Author(s)

This is an Open Access article distributed under the terms of the Creative Commons Attribution Non-Commercial License (https://creativecommons.org/licenses/by-nc/4.0/) which permits unrestricted non-commercial use, distribution, and reproduction in any medium, provided the original work is properly cited. after controlling for some particular host nations' features (Borensztein et al., 1998; Alfaro et al., 2004; Fortanier, 2007; Erum et al., 2016; Nguyen, 2020; Tung \& Thang, 2020), a number of studies indicate opposite outcomes (Saltz, 1992; Mencinger, 2003). Part of the reason may lie in the choice of theoretical frameworks and the specification of FDI mode of entry. Accordingly, on the one hand, greenfield FDI (referring to the establishment of new companies) is often found to exert economic-boosting influence on the host countries through the process of capital enhancement, jobs creation and thereby economic development (Wang \& Wong, 2009). M\&A (full or partial takeover of companies by foreign investors), on the other hand, is generally known as a speculative strategy that seeks the arbitrage profits only (Kim, 2008). For this reason, it neither increases the capital stock nor improves economic productivity, and thus might have no beneficial impact on the host nations. It is also worth noting that, although there are a lot of studies focusing on the important role of infrastructure in attracting FDI inflows (i.e., Anh, 2006; Y1lmaz, 2017), no study so far concentrates on how FDI affects the public-service sectors' development, leaving this question still unanswered. 
Previous studies also show that corruption level is an important factor that can moderate the impact of FDI on the development of the host country (Meyer \& Nguyen, 2005). The literature on the corruption-FDI nexus (i.e., Mudambi et al., 2013) has often recognized the possibility that corruption is detrimental and a barrier to entry since it is seen as an added tax that augments operating expenses. In addition, since bribery is unofficial and (most likely) illegal, the firm will be vulnerable to losses and be unprotected if the corrupt officers do not fulfill their promises. However, another strand of literature (e.g., Barassi \& Zhou, 2012) suggests a contrasting view where corruption can be referred to the "grease for the squeaky wheels", helping to increase market efficiency, reducing the firm's business expenses, and eventually allowing MNCs to penetrate the market.

Recently, attention has shifted to another important, but less explored channel, which is public-sector services, particularly in developing countries (Imam et al., 2019; Wren-Lewis, 2015; Estache et al., 2009; Dal Bó \& Rossi, 2006; Bergara et al., 1998). The preponderance of evidence from this strand of literature suggests that corruption can inhibit the performance of public-goods sectors. For example, in a recent study, Imam et al. (2019) investigate the influence of corruption on electricity sector performance in Sub-Saharan African countries. They find that corruption can significantly reduce technical efficiency of the sector and constrain the efforts to increase access to electricity and national income; while examining the corruption-electricity sector performance linkage in different settings, they also capture similar outcomes as Imam et al. (2019). In another strand of literature, Yan and Oum (2014) argue that the cost of providing public goods is affected by corruption of local government since bureaucrats have no strong incentives to pursue mandated tasks under a corrupt environment.

Unfortunately, the empirical literature examining the impacts of FDI and corruption on receiving countries reveals rather mixed and inconclusive outcomes, perhaps due to the fact that the aggregated FDI level can actually be categorized into small components such as greenfield investment or crossborder M\&As), and thus the corresponding effects of those FDI compositions and corruption might be different. It is also believed that foreign investors, when encountering corruption, used to choose an appropriate mode of entry to take advantage of corruption as well as reduce uncertainty risk (Brouthers et al., 2008). In particular, while greenfield FDI (referring to the establishment of new companies) can exert economic-boosting influences thanks to the increase of capital, the creation of more jobs as well as the development of economics as described earlier, M\&As (full or partial takeover of companies by foreign investors), in contrast, might have no beneficial impact on the host nations due to their speculative nature.

The purpose of this study therefore fills these research gaps by investigating the impact of FDI and corruption on the development of public-service sectors in several ASEAN nations. Accordingly, this research can contribute to the economics literature by providing empirical evidence about the FDI-public-service sector development nexus, while explicitly controlling for corruption practice. Second, it will provide a deep insight into this relationship by examining how each FDI composition could elicit different influences on the host countries' development. Finally, this study will provide the first empirical evidence about the link between FDI, corruption and public-service sectors' development in ASEAN countries, which has been neglected recently since much attention so far have been paid to developed countries.

Using a panel database from 10 emerging countries during the period 1996-2015, we first find that FDI strongly and positively contribute to the development of the publicservice sectors in the recipient nations, except for electricity sector. However, we show that this relationship is dependent on the type of FDI modes of entry. Specifically, while greenfield investments positively affect the development of telecommunication and transportation sectors, cross-border M\&A has no beneficial influence, perhaps because of the distinct differences among three public-service sectors. Finally, we document that, when controlling for corruption, the study can show a more complete picture about the influence of FDI and its two components on the development of public-service sectors. In particular, we found that in a corrupt environment, aggregate FDI might have no influence on all three public-service sectors, possibly because the two contradictory influences of corruption and two FDI components on the development of public-service sectors seem to cancel each other out.

The paper proceeds as follow. Section 2 describes the methodology. Section 3 presents and discusses the empirical results. Section 4 provides conclusion and discussion.

\section{Methodology}

\subsection{Model Specification}

In order to examine the effect of FDI on the development of public-service sectors, we use the following model:

$$
\gamma_{i t}=\varphi_{1} F_{i t}+\varphi_{2} \text { Corruption }_{i t}+\varphi_{3}^{K} X_{i t}^{\prime \prime}+v_{j}+\eta_{t}+\mu_{t}^{1}
$$

Of which $\gamma_{\text {it }}$ is the development level of public-service sectors, proxies by three indicators including electricity, transportation and telecommunication. $i$ and $t$ are country and time. As suggested by some previous studies (i.e., Randolph et al., 1996; Calderón et al., 2015), these three sectors are the most important measures of the degree of development of public-service sectors in a country. Specifically, electricity is calculated as the percentage of households with access to 
electricity. Telecommunication is defined as total number of telephone lines (fixed and mobile) per 100 people. Transportation is measured as a natural logarithm of total air and rail transportations. Regarding other variables Corruption is the level of corruption that is retrieved from the Worldwide Governance Indicators, the World Bank. FDI is calculated by the share of FDI inflows to GDP. $\boldsymbol{X}^{\prime \prime}=$ [Natural resource, population, national income, government consumption, tax, human capital] is the vector of $\mathrm{j}$ covariates that has often been used in development economic literature and potentially influence the development of public-service sectors. Finally, $v_{\mathrm{j}}$ and $\eta_{\mathrm{t}}$ are country and year fixed effects and $\mu_{t}^{1}$ is the error term.

To examine the effect of FDI components, we replace the FDI variable by Greenfield, measured by the share of greenfield investment sales to GDP and Merger, calculated by the ratio of cross-border M\&A sales to GDP as follows:

$$
\begin{aligned}
\gamma_{i t} & =\varphi_{0}+\varphi_{1} \text { green field }_{i t}+\varphi_{1} \text { corruption }_{i t} \\
& +\varphi_{3}^{K} X_{i t}^{\prime \prime}+v_{j}+\eta_{t}+\mu_{t}^{3} \\
\gamma_{i t} & =\varphi_{0}+\varphi_{1} \text { mergen }_{i t}+\varphi_{2} \text { corruption }_{i t} \\
& +\varphi_{3}^{K} X_{i t}^{\prime \prime}+v_{j}+\eta_{t}+\mu_{t}^{3}
\end{aligned}
$$

\subsection{Sample Overview}

We use a sample of 10 ASEAN countries between the period of 1996 and 2015. All the data is retrieved and merged from UNCTAD and the World Development Indicators database. Our final dataset contains 172 observations from
10 ASEAN countries between 1996 and 2015. Descriptive statistics and the correlation matrix between all variables are provided in Table 2 and Table 3, respectively.

\section{Empirical Results}

\subsection{The Impact of the Aggregated FDI on the Development of Public Service Sectors}

Column 1 on Table 4 shows the results of the electricity as a dependent variable, column 2 reports the regression results when the telecommunication is used, whereas column 3 depicts the results for transportation sector.

Overall, as can be seen from Table 4, the estimated coefficients on FDI are always positive and strongly significant in all three specifications, implying that FDI may contribute positively to the development of public service sectors in the host countries. Our results are, therefore, in line with some prior studies (i.e., Borensztein et al., 1998; De Mello, 1999; Alfaro et al., 2004 and Fortanier, 2007). Accordingly, this positive relationship can be explained by the fact that FDI has increased the stock of knowledge of the host country via the spillover effects from FDI investors to local firms and fostered technological growth via the incorporation of new inputs and foreign technologies in the production of the host country. In addition, since FDI investors can provide a large amount of capital for the recipient country, these countries can use this money to improve their telecommunication, transportation and electricity system to better serve the society.

Table 1: Definitions, measurements and sources of main variables

\begin{tabular}{|l|l|l|}
\hline Variable & \multicolumn{1}{|c|}{ Definition and measurement } & \multicolumn{1}{c|}{ Source } \\
\hline Electricity & $\begin{array}{l}\text { Percentage of population with access to electricity to } \\
\text { total population }\end{array}$ & World Development Indicators \\
\hline Transportation & Natural logarithm of total air and rail transportations & World Development Indicators \\
\hline Telecommunication & Total telephone lines (fixed and mobile) per 100 people & World Development Indicators \\
\hline FDI & Percentage of FDI to GDP & UNCTAD \\
\hline Merger & Percentage of merger sales to GDP & UNCTAD \\
\hline Greenfield & Percentage of greenfield sales to GDP & UNCTAD \\
\hline Corruption & The corruption index provided by the World Bank & Worldwide Governance Indicators \\
\hline Natural resource & Total natural resource rents & Worldwide Governance Indicators \\
\hline Population & Total population number & World Development Indicators \\
\hline National Income & Real per capita income & World Development Indicators \\
\hline Govconsumption & The consumption level of government & World Development Indicators \\
\hline Tax & Taxes on income, profits and capital gains to revenue & World Development Indicators \\
\hline Human capital & Primary (or Secondary) completion rate & World Development Indicators \\
\hline
\end{tabular}


Table 2: Summary Statistics

\begin{tabular}{|l|c|c|c|c|c|}
\hline Variable & Obs & Mean & S.D & Min & Max \\
\hline Electricity & 199 & 78.716 & 25.295 & 5.136 & 100.000 \\
\hline Telecommunication & 199 & 65.888 & 57.881 & 0.348 & 192.269 \\
\hline Transportation & 199 & 15.019 & 2.657 & 3.497 & 18.301 \\
\hline FDI & 195 & 0.057 & 0.065 & -0.028 & 0.503 \\
\hline Greenfield & 195 & 0.052 & 0.063 & -0.032 & 0.503 \\
\hline Merger & 147 & 0.006 & 0.013 & -0.048 & 0.072 \\
\hline Corruption & 170 & 40.651 & 28.965 & 0.474 & 98.571 \\
\hline Natural resource & 146 & 19.632 & 23.805 & 0.001 & 96.622 \\
\hline Population & 199 & 16.869 & 1.806 & 12.620 & 19.367 \\
\hline National_income & 195 & 7.798 & 1.573 & 4.900 & 10.895 \\
\hline Govconsumption & 176 & 0.694 & 0.155 & 0.324 & 1.037 \\
\hline Human capital & 172 & 0.494 & 0.165 & 0.264 & 1.787 \\
\hline Tax & 136 & 32.733 & 11.340 & 5.662 & 59.495 \\
\hline
\end{tabular}

Table 3: Correlation matrix

\begin{tabular}{|c|c|c|c|c|c|c|c|c|c|c|c|c|c|}
\hline & 1 & 2 & 3 & 4 & 5 & 6 & 7 & 8 & 9 & 10 & 11 & 12 & 13 \\
\hline 1. Telecommunication & 1 & & & & & & & & & & & & \\
\hline 2. Transportation & 0.401 & 1 & & & & & & & & & & & \\
\hline 3. Electricity & 0.661 & 0.268 & 1 & & & & & & & & & & \\
\hline 4. FDI & 0.367 & 0.341 & 0.286 & 1 & & & & & & & & & \\
\hline 5. Merger & 0.297 & 0.195 & 0.107 & 0.368 & 1 & & & & & & & & \\
\hline 6. Greenfield & 0.358 & 0.087 & 0.296 & 0.372 & 0.224 & 1 & & & & & & & \\
\hline 7. Corruption & -0.312 & -0.235 & -0.256 & -0.163 & -0.311 & -0.104 & 1 & & & & & & \\
\hline 8. Natural resource & 0.67 & 0.311 & 0.6 & 0.309 & 0.349 & 0.247 & -0.240 & 1 & & & & & \\
\hline 9. Population & 0.544 & 0.134 & 0.561 & 0.103 & 0.244 & 0.043 & -0.557 & 0.185 & 1 & & & & \\
\hline 10. National income & 0.244 & -0.259 & 0.352 & -0.289 & -0.237 & -0.262 & -0.505 & 0.196 & 0.301 & 1 & & & \\
\hline 11. Govconsumption & -0.092 & -0.076 & -0.157 & 0.049 & 0.157 & 0.004 & 0.268 & -0.243 & -0.295 & -0.325 & 1 & & \\
\hline 12. Human capital & 0.344 & 0.764 & 0.321 & 0.253 & 0.324 & 0.753 & -0.237 & 0.345 & 0.203 & 0.534 & 0.142 & 1 & \\
\hline 13. Tax & 0.133 & -0.175 & 0.192 & -0.138 & -0.391 & -0.062 & 0.351 & -0.360 & -0.411 & 0.225 & 0.146 & 0.282 & 1 \\
\hline
\end{tabular}

In terms of the relationship between corruption and the development of public-service sectors, Table 4 shows that corruption has no impact on the development of publicservice sectors. This finding implies that the influence of corruption might be much more complicated and thus need further in-depth exploration.

\subsection{The Impact of FDI Compositions on the Development of Public-Service Sectors}

Previous empirical works (i.e., Kogut \& Singh, 1988; Hennart \& Park, 1993; Mayer et al., 2009; Gopalan et al., 2017) have suggested that FDI is, in fact, comprised of 
Table 4: The impact of aggregated FDI on the development of public service sectors in ASEAN countries

\begin{tabular}{|l|c|c|c|}
\hline & $\mathbf{( 1 )}$ & $\mathbf{( 2 )}$ & $\mathbf{( 3 )}$ \\
\hline VARIABLES & electricity & telecommunication & transportation \\
\hline FDI & -0.317 & -7.819 & 1.881 \\
\hline Corruption & $(3.763)$ & $(1.783)$ & $(1.487)$ \\
\hline & -0.059 & -0.056 & $0.009^{* * *}$ \\
\hline Natural resource & $(0.052)$ & $(0.237)$ & $(0.003)$ \\
\hline & -0.041 & $-0.999^{* * *}$ & -0.004 \\
\hline Population & $(0.079)$ & $(0.360)$ & $0.005)$ \\
\hline & $-1.351^{* *}$ & 0.443 & 0.015 \\
\hline National_income & $(0.534)$ & $(2.446)$ & $0.033)$ \\
\hline & $2.337^{* *}$ & $9.512^{* *}$ & $(0.947)$ \\
\hline Govconsumption & $(1.145)$ & $(3.329)$ & $1.195^{* *}$ \\
\hline & $3.982^{* *}$ & 2.076 & $(0.578)$ \\
\hline Tax & $(9.237)$ & $(2.283)$ & -0.000 \\
\hline & -0.124 & $-1.020^{* *}$ & $(0.006)$ \\
\hline Human capital & $(0.102)$ & $(0.467)$ & $0.006^{* *}$ \\
\hline & $0.247^{* * *}$ & 0.193 & $(0.004)$ \\
\hline Constant & $(0.066)$ & $(0.302)$ & $-1.389^{* * *}$ \\
\hline & $-2.308^{* *}$ & $-2.841^{* * *}$ & $(5.753)$ \\
\hline Observations & $(1.967)$ & $(1.002)$ & 172 \\
\hline R-squared & 172 & 172 & 0.913 \\
\hline Number of CountryCode & 0.681 & 0.926 & 10 \\
\hline
\end{tabular}

Standard errors in parentheses. ${ }^{* *} p<0.01,{ }^{* *} p<0.05,{ }^{*} p<0.1$

different components and argued that these two forms of investment may produce differential impacts on the host country due to their differences in nature and, thus, cannot perfectly be substituted for each other. According to the transaction cost theory, MNCs tend to undertake FDI in the form of greenfield investment when they seek to exploit their superior managerial abilities and technical expertise as well as intensify R\&D (Chang \& Rosenzweig, 2001). In contrast, cross-border M\&As are often preferred by MNCs as a way to secure key resources of the domestic countries and acquire product-specific knowledge of the local firms (Chang \& Rosenzweig, 2001) because this type of entry mode usually involves the ownership transfer of existing assets and resources from domestic to foreign entities. Therefore, in order to examine whether each type of FDI components could have different impacts on the development of public-service sectors in the host country, we estimate model (2) and (3). Our results are then presented in Table 5.

The results from Table 5 show that greenfield investments positively affect the development of all three public-service sectors since the coefficients of Greenfield are positive and significant in all three models (1)-(2)-(3). Our results, therefore, lend support for the proposition that greenfield investment can exert economicboosting influences by increasing capital stock, creating jobs, and boosting economic development (Wang \& Wong, 2009).

In contrast, since the coefficients of Merger are insignificant in all specifications, ours findings imply that FDI, in the form of cross-border M\&A, exerts no impact on the development of public-service sectors. This results can be explained by the fact that, since M\&A (full or partial takeover of companies by foreign investors) are viewed as a speculative strategy that seeks the arbitrage profits, it in fact leads to no beneficial impact on the host nations.

In terms of corruption, our results show that, regardless of the FDI types, the impact of corruption is always insignificant. However since the signs of corruption are contrasting between two forms of investment, it suggests that corruption might somehow have different impacts. 
Table 5: The impact of FDI compositions on the Development of Public Service Sectors in ASEAN countries

\begin{tabular}{|c|c|c|c|c|c|c|}
\hline & (1) & $(2)$ & (3) & (4) & (5) & (6) \\
\hline VARIABLES & electricity & telecommunication & transportation & electricity & telecommunication & transportation \\
\hline \multirow{2}{*}{ Greenfield } & $3.631^{* * *}$ & $2.241^{* * *}$ & $0.033^{* * *}$ & & & \\
\hline & (1.183) & $(4.664)$ & $(0.645)$ & & & \\
\hline \multirow[t]{2}{*}{ Merger } & & & & -0.991 & -9.071 & 0.121 \\
\hline & & & & (9.721) & (4.785) & (0.665) \\
\hline \multirow[t]{2}{*}{ Corruption } & 0.056 & 0.055 & 0.010 & -0.028 & -0.093 & -0.010 \\
\hline & $(0.052)$ & $(0.240)$ & $(0.003)$ & $(0.050)$ & $(0.251)$ & $(0.003)$ \\
\hline \multirow[t]{2}{*}{ Natural resource } & $0.041^{* *}$ & $1.009^{* * \star}$ & $0.003^{* * *}$ & $0.072^{\star \star \star}$ & $1.113^{\star * *}$ & $0.005^{\star \star}$ \\
\hline & $(0.077)$ & $(0.355)$ & $(0.005)$ & $(0.076)$ & $(0.382)$ & $(0.005)$ \\
\hline \multirow[t]{2}{*}{ Population } & $-1.369^{* * *}$ & 0.651 & -0.008 & $-1.896^{* * *}$ & -0.618 & -0.019 \\
\hline & $(0.449)$ & (2.059) & $(0.028)$ & $(0.477)$ & $(2.395)$ & $(0.033)$ \\
\hline \multirow[t]{2}{*}{ National_income } & $3.210^{*}$ & $4.197^{* \star \star}$ & $1.302^{\star *}$ & $2.300^{* \star}$ & $14.242^{* *}$ & $1.378^{\star \star}$ \\
\hline & $(1.202)$ & $(0.498)$ & $(0.836)$ & $(1.254)$ & $(1.497)$ & $(0.839)$ \\
\hline \multirow[t]{2}{*}{ Govconsumption } & $3.094^{\star * *}$ & $2.519^{* * *}$ & $1.142^{*}$ & $5.568^{\star \star *}$ & $4.330^{* *}$ & $1.843^{* *}$ \\
\hline & (9.210) & (2.204) & $(0.583)$ & $(11.149)$ & $(5.947)$ & $(0.763)$ \\
\hline \multirow[t]{2}{*}{ Tax } & -0.124 & $-1.035^{\star \star}$ & 0.002 & $-0.166^{*}$ & $-0.964^{\star \star}$ & 0.001 \\
\hline & $(0.100)$ & $(0.457)$ & $(0.006)$ & $(0.095)$ & $(0.476)$ & $(0.006)$ \\
\hline \multirow[t]{2}{*}{ Human capital } & $0.248^{* * *}$ & $0.213^{* *}$ & $0.003^{* *}$ & $0.242^{\star * *}$ & 0.173 & 0.004 \\
\hline & $(0.060)$ & $(0.277)$ & $(0.004)$ & $(0.059)$ & $(0.294)$ & $(0.004)$ \\
\hline \multirow[t]{2}{*}{ Constant } & $-2.835^{\star \star}$ & $-2.046^{\star * \star}$ & $-1.141^{* * *}$ & $-4.528^{\star \star \star}$ & $-2.977^{\star \star \star}$ & $-2.243^{\star \star *}$ \\
\hline & (2.365) & $(4.270)$ & $(5.847)$ & (2.412) & $(4.878)$ & $(6.804)$ \\
\hline Observations & 172 & 172 & 172 & 172 & 172 & 172 \\
\hline R-squared & 0.682 & 0.926 & 0.911 & 0.746 & 0.927 & 0.913 \\
\hline No of Country & 10 & 10 & 10 & 10 & 10 & 10 \\
\hline
\end{tabular}

Standard errors in parentheses. ${ }^{* * *} p<0.01,{ }^{* *} p<0.05,{ }^{*} p<0.1$

\subsection{Interactive Analysis}

The level of corruption in the host nation is often viewed as a critical factor that affects the FDI investors' choice of FDI location. On the one hand, corruption is recognized as an additional expense that investors must pay to obtain government favors, business licenses and other activities permits. As a consequence, corruption can reduce the profit of investment (Bardhan, 1997), hinder investment opportunities (Mauro, 1995), weaken public infrastructure and services (Gupta et al., 2000) as well as destroy social equality ( $\mathrm{Li}$ et al., 2000). On the other hand, foreign investors also utilize corruption as an effective tool to speed up the decision-making process and deal with inefficient bureaucracy (Bardhan, 1997). Until now, there still is a lack of evidence about what is the true impact of corruption and FDI on the host nations. Thus, our research will dig deeper into this relationship in the areas of public-service sectors in several ASEAN countries by adding the interaction terms between corruption and FDI as well as its two compositions into our baseline models. Our findings are then illustrated in Table 6 as follows:

The results from Table 6 show that the estimated coefficients of the interaction terms Corruption_FDI remain unchanged, suggesting that corruption has no significant influence on the host countries. However, it is very interesting to see that this impact turns out to be significant and different when its interaction terms with Greenfield and Merger are taken into account. Specifically, while the coefficients on the interaction terms Corruption_Merger are significantly positive in the Telecommunication and Transportation model, they are insignificant in Electricity models. The possible reason for this is that market penetration through cross-border M\&A are more likely to occur in countries that have high corruption levels because it enables investors to reduce the costs arising from unnecessary tangled procedures and mitigate the opportunistic behavior risk. In addition, since cross-border M\&As involves the ownership transfer of existing assets and resources from domestic to foreign entities, this entry mode could allow foreign 
Table 6: The joint impact of FDI and corruption on the development of public service sectors in ASEAN countries

\begin{tabular}{|c|c|c|c|c|c|c|c|c|c|}
\hline & (1) & $(2)$ & (3) & (4) & (5) & (6) & (7) & (8) & (9) \\
\hline VARIABLES & & electricity & & \multicolumn{3}{|c|}{ telecommunication } & \multicolumn{3}{|c|}{ transportation } \\
\hline \multirow[t]{2}{*}{ FDI } & -13.894 & & & -1.736 & & & -3.631 & & \\
\hline & $(3.827)$ & & & $(1.706)$ & & & $(2.388)$ & & \\
\hline \multirow[t]{2}{*}{ Greenfield } & & $5.954^{* *}$ & & & $6.039^{*}$ & & & $4.347^{* *}$ & \\
\hline & & $(0.985)$ & & & $(1.821)$ & & & $(1.899)$ & \\
\hline \multirow[t]{2}{*}{ Merger } & & & $-1.469^{*}$ & & & $-1.156^{*}$ & & & $-6.382^{* * *}$ \\
\hline & & & $(7.861)$ & & & $(4.997)$ & & & $(4.684)$ \\
\hline \multirow[t]{2}{*}{ Corruption } & -0.043 & $-0.042^{* *}$ & $-0.043^{* *}$ & $-0.055^{\star *}$ & $-0.060^{* *}$ & -0.301 & $-0.012^{* *}$ & $-0.012^{* *}$ & $-0.014^{* * *}$ \\
\hline & $(0.090)$ & $(0.089)$ & $(0.087)$ & $(0.418)$ & $(0.415)$ & $(0.412)$ & $(0.006)$ & $(0.005)$ & $(0.005)$ \\
\hline \multirow[t]{2}{*}{ cor_FDI } & 0.328 & & & 1.652 & & & 0.055 & & \\
\hline & $(0.492)$ & & & $(2.299)$ & & & $(0.031)$ & & \\
\hline \multirow[t]{2}{*}{ cor_green } & & -0.348 & & & $-1.666^{* *}$ & & & $-0.064^{* *}$ & \\
\hline & & $(0.415)$ & & & $(1.941)$ & & & $(0.025)$ & \\
\hline \multirow[t]{2}{*}{ cor_merger } & & & 2.082 & & & $3.257^{* *}$ & & & $0.411^{* * *}$ \\
\hline & & & $(1.957)$ & & & $(9.728)$ & & & $(0.115)$ \\
\hline \multirow[t]{2}{*}{ Natural_resource } & $0.076^{* * *}$ & $0.086^{* *}$ & $0.078^{* * *}$ & $1.709^{* * *}$ & $1.685^{* * *}$ & $1.456^{* * *}$ & $0.013^{* *}$ & $0.012^{*}$ & $0.011^{* *}$ \\
\hline & $(0.120)$ & $(0.119)$ & $(0.117)$ & $(0.560)$ & $(0.556)$ & $(0.527)$ & $(0.008)$ & $(0.007)$ & $(0.007)$ \\
\hline \multirow[t]{2}{*}{ Population } & 1.727 & 1.874 & 2.054 & 6.167 & 6.766 & 2.778 & 0.192 & $0.210^{*}$ & $0.321^{* *}$ \\
\hline & $(1.905)$ & $(1.936)$ & $(2.126)$ & $(8.901)$ & $(9.048)$ & $(9.976)$ & $(0.120)$ & $(0.119)$ & $(0.125)$ \\
\hline \multirow[t]{2}{*}{ National_income } & $3.740^{* *}$ & $3.502^{* *}$ & $3.474^{*}$ & $2.270^{*}$ & $2.036^{\star *}$ & $4.677^{*}$ & $1.587^{*}$ & $1.528^{*}$ & $0.913^{*}$ \\
\hline & $(2.747)$ & $(2.574)$ & $(2.186)$ & $(1.291)$ & $(1.552)$ & $(1.743)$ & $(1.815)$ & $(1.751)$ & $(1.653)$ \\
\hline \multirow[t]{2}{*}{ govconsumption } & $1.492^{* * *}$ & $1.822^{* * *}$ & $2.779^{* * *}$ & $3.966^{* *}$ & $3.249^{* *}$ & $1.315^{* *}$ & $0.913^{* *}$ & $1.024^{* *}$ & $0.818^{* * *}$ \\
\hline & $(1.603)$ & $(9.588)$ & $(1.906)$ & $(1.575)$ & $(1.552)$ & $(4.574)$ & $(1.237)$ & $(1.200)$ & $(1.167)$ \\
\hline \multirow[t]{2}{*}{ Tax } & -0.068 & -0.066 & -0.103 & -0.106 & -0.100 & -0.146 & 0.006 & 0.007 & 0.002 \\
\hline & $(0.178)$ & $(0.176)$ & $(0.170)$ & $(0.829)$ & $(0.821)$ & $(0.744)$ & $(0.011)$ & $(0.011)$ & $(0.010)$ \\
\hline \multirow[t]{2}{*}{ Human capital } & $0.146^{\star *}$ & $0.148^{*}$ & $0.211^{*}$ & $0.368^{*}$ & $0.336^{*}$ & $0.649^{* *}$ & $0.012^{*}$ & $0.013^{*}$ & 0.009 \\
\hline & $(0.108)$ & $(0.105)$ & $(0.119)$ & $(0.506)$ & $(0.489)$ & $(0.532)$ & $(0.007)$ & $(0.006)$ & $(0.007)$ \\
\hline \multirow[t]{2}{*}{ Constant } & $-1.249^{* * *}$ & $-1.650^{* * *}$ & $-0.795^{* * *}$ & $-2.246^{* * *}$ & $-2.658^{* * *}$ & $-1.073^{*}$ & $-2.451^{* *}$ & $-2.536^{* *}$ & $-2.818^{*}$ \\
\hline & $(0.898)$ & $(0.916)$ & $(0.755)$ & $(3.493)$ & $(9.061)$ & $(5.005)$ & (1.682) & $(2.312)$ & $(2.009)$ \\
\hline Observations & 172 & 172 & 172 & 172 & 172 & 172 & 172 & 172 & 172 \\
\hline R-squared & 0.824 & 0.825 & 0.810 & 0.934 & 0.935 & 0.945 & 0.914 & 0.919 & 0.926 \\
\hline No. of Country & 10 & 10 & 10 & 10 & 10 & 10 & 10 & 10 & 10 \\
\hline
\end{tabular}

Standard errors in parentheses. ${ }^{* * *} p<0.01,{ }^{* *} p<0.05,{ }^{*} p<0.1$

investors to faster market entry, obtain immediate access to local resources, inherit the long-lasting relationships with domestic government authorities from their target firms, and ultimately could foster the development of public service sectors in the host countries (Meyer \& Estrin, 2001).

On the other hand, the coefficients of the interaction terms Corruption_Greenfield are negative in Telecommunication and Transportation model and are insignificant in Electricity model. This results suggest that, in a highly corrupt environment, greenfield investments contribute no developmental value since FDI investors must allocate a great amount of money to address corruption, leading to an increase in business expenses and risks and a reduction of profit. As a consequence, they have little or no developmental impact on recipient countries (Bardhan, 1997; Tanzi \& Davoodi, 1997).

Overall, it appears that these two contradictory influences of corruption and FDI components on public-service sectors seem to cancel each other out, making the impact of aggregated FDI and corruption insignificant regardless of different types of sectors examined. More interesting, the insignificant impacts on the electricity sector imply that there are some unique characteristics that distinguish the electricity sector from the other two public service sectors. In particular, the electricity sector is usually known as having monopoly power and high protection from government. As a result, FDI 
flow in electricity may exert no value just because foreign investors have very little chance to access resources and obtain business licenses. Meanwhile, since telecommunication and transportation sectors have become increasingly competitive markets and attracted greatest amount of FDI thanks to technological changes, regulatory innovations and the quick removal of their monopoly status. In this respect, FDI investors have more opportunities to operate in telecommunication and transportation sectors and, thus, they could contribute to the development of these sectors.

\section{Conclusion and Discussion}

The main purpose of this study is to empirically investigate the effect of foreign direct investment (FDI) and corruption on the development of public service sectors in recipient nations. It further investigates the effect of two FDI sub-types and corruption on the development of public service facilities in 10 ASEAN countries.

Using a panel database from 10 emerging countries between 1996 and 2015, we first find that FDI strongly and positively contributes to the development of the publicservice sectors in the recipient nations, except for the electricity sector. We further find that, while greenfield investment has a positive influence on the development of telecommunication and transportation sectors, cross-border M\&A has no developmental impact, possibly due to their differences in nature and, thus, they may produce different impacts on the host country. We also document that, when controlling for corruption, the study can provide a more indepth insight into the impact of FDI and its two components. We found that in a corrupt environment, aggregate FDI might have no influence on all three public-service sectors, possibly because the two contradictory influences of corruption and two types of FDI components seem to cancel each other out.

Taken together, our study may contribute to the literature by providing evidence that, since the modes of entry are different in nature, they can have different influences on the development of public-service sectors. These findings therefore suggest that policymakers, when building their strategy to attract FDI, should take the modes of entry into consideration since only FDI investment in the form of greenfield can have a positive impact on the recipient countries. However, in order to benefit more from FDI activities, emerging countries need to control the level of corruption because, in a highly corrupt environment, greenfield investment might contribute no developmental impact on the host countries. In addition, the different impact of FDI among the three public-service sectors also implies that FDI investors need to focus on areas where they possess advantages (i.e., superior experts and technological advances like telecommunication) and be wary of participating in areas that continue to be very government-dependent such as electricity to reduce risks and uncertainties.

\section{References}

Alfaro, L., Chanda, A., Kalemli-Ozcan, S., \& Sayek, S. (2004). FDI and economic growth: The role of local financial markets. Journal of International Economics, 64(1), 89-112.

Anh, N. T. N. (2016). Regional determinants of FDI location in Vietnam. Journal of Economic Development, 18, 19-37.

Barassi, M. R., \& Zhou, Y. (2012). The impact of corruption on FDI: A parametric and nonparametric analysis. European Journal of Political Economy, 28(3), 302-312.

Bardhan, P. (1997). Corruption and Development: A Review of Issues. Journal of Economic Literature, 35(3), 1320-1346.

Bergara, M. E., Henisz, W. J., \& Spiller, P. T. (1998). Political institutions and electric utility investment: a cross-nation analysis. Program on Workable Energy Regulation (POWER). California Management Review, 40(2), 18-35.

Borensztein, E., De-Gregorio, J., \& Lee, J.-W. (1998). How does foreign direct investment affect economic growth? Journal of International Economics, 45(1), 115-135.

Brouthers, L.E. Gao, Y., \& McNicol, J.P. (2008). Corruption and market attractiveness influences on different types of FDI. Strategic Management Journal, 29(6), 673-680.

Calderón, C., \& Servén, L. (2010). Infrastructure and Economic Development in Sub-Saharan Africa. Journal of African Economies, 19(1), 13-89.

Chang, S. J., \& Rosenzweig, P. M. (2001). The choice of entry mode in sequential foreign direct investment. Strategic Management Journal, 22(8), 747-776.

Dal Bó, E., \& Rossi, M. A. (2007). Corruption and inefficiency: theory and evidence from electric utilities. Journal of Public Economics, 91(5-6), 939-962.

De Mello, L. R. (1999). Foreign direct investment-led growth: Evidence from time series and panel data. Oxford Economic Papers, 51(1), 133-151.

Erum, N., Hussain, S., \& Yousaf, A. (2016). Foreign direct investment and economic growth in Saarc countries. Journal of Asian Finance, Economics and Business, 3(4), 57-66. https:// doi.org/10.13106/jafeb.2016.vol3.no4.57

Estache, A., Tovar, B., \& Trujillo, L. (2008). How efficient are African electricity companies? Evidence from the Southern African countries. Energy policy, 36(6), 1969-1979.

Fortanier, F. (2007). Foreign direct investment and host country economic growth: Does the investor's country of origin play a role. Transnational Corporations, 16(2), 41-76.

Gopalan, S. Ouyang, A., \& Rajan. R. S. (2017). Impact of Greenfield FDI versus M\&A on growth and domestic investment in developing Asia. Economia Politica, 35(1), 41-70. 
Hennart, J. F., \& Park, Y. R. (1993). Greenfield vs. acquisition: The strategy of Japanese investors in the United States. Management science, 39(9), 1054-1070.

Imam, M. I, Jamasb, T., \& Llorca, M. (2019). Sector reforms and institutional corruption: Evidence from electricity industry in Sub-Saharan Africa. Energy Policy. 129, 532-545.

Kogut, B., \& Singh, H. (1988). The effect of national culture on the choice of entry mode. Journal of International Business Studies, 19(3), 411-432.

Kim, Y. H. (2008). Cross-border M\&A vs. Greenfield FDI: economic integration and its welfare impact. Journal of Policy Modeling, 31(1), 87-101.

Mauro, P. (1995). Corruption and growth. Quarterly Journal of Economics, 110, 681-712.

Meyer, K. S., \& Nguyen, H. V. (2005). Foreign Investment Strategies and Sub-National Institutions in Emerging Markets. Journal of Management Studies, 42(1), 63-93.

Meyer, K. S., \& Estrin, S. (2001). Brownfield Entry in Emerging Market. Journal of International Business Studies, 32(3), 575-584.

Meyer, K. E. Estrin, S. Bhaumik, S. K., \& Peng, M. W. (2009). Institutions, Resources, and Entry Strategies in Emerging Economies. Strategic Management Journal, 30(1), 61-80.

Mencinger, J. (2003). Does foreign direct investment always enhance economic growth? Kyklos, 56(4), 491-508.

Mudambi, R. Navarra, P., \& Delios, A. (2013). Government regulation, corruption, and FDI. Asian Pacific Journal of Management, 30(2), 487-511.

Nguyen, H. H. (2020). Impact of Foreign Direct Investment and International Trade on Economic Growth: Empirical Study in Vietnam. Journal of Asian Finance, Economics, and Business, 7(3), 323-331. https://doi.org/10.13106/jafeb.2020.vol7.no3.323
Randolph, S., Bogetic, Z., \& Hefleyet, D. (1996). Determinants of Public Expenditure on Infrastructure: Transportation and Communication. World Bank Policy Research Working Paper No. 1661. https://doi.org/10.1596/1813-9450-1661

Saltz, I. S. (1992). The negative correlation between foreign direct investment and economic growth in the third world: Theory and evidence. Rivista Internazionale Di Scienze Economiche E Commerciali, 39(7), 617-33.

Tanzi, V., \& Davoodi, H. (1997). Corruption, public investment, and growth. IMF Working Paper WP/97/139. https://www.imf. org/external/pubs/ft/wp/wp97139.pdf

Tung, L. T., \& Thang, P. N. (2020). Impact of FDI on Private Investment in the Asian and African Developing Countries: A Panel-Data Approach. Journal of Asian Finance, Economics, and Business, 7(3), 295-302. https://doi.org/10.13106/ jafeb.2020.vol7.no3.295.

Wang, M., \& Wong, S. (2009). What drives economic growth? The case of cross-border M\&A and greenfield FDI activities, Kyklos, 62(2), 316-330.

Wren-Lewis, L. (2015). Do Infrastructure Reforms Reduce the Effect of Corruption? Theory and Evidence from Latin America and the Caribbean. New York, NY: Oxford University Press.

Yan, J., \& Oum, T. H. (2014). The effect of government corruption on the efficiency of US commercial airports. Journal of Urban Economics, 80, 119-132.

Yilmaz, G. (2017). Public infrastructure investment and development: Evidence from Turkey. Journal of Economics and Development, 19(3), 68-90. DOI: 10.33301/2017.19.03.05 